\title{
KAJIAN RANCANGAN INSTALASI PENERANGAN PADA LABORATORIUM EKSPLORASI DAN MEKANIKA BATUAN POLITEKNIK MUARA TEWEH
}

\author{
Juli Chandra Teruna ${ }^{1}$ \\ Staf Pengajar Politeknik Muara Teweh ${ }^{1}$ \\ julichandra19@gmail.com ${ }^{1}$
}

\begin{abstract}
Abstrak - Politeknik Muara Teweh memiliki fasilitas gedung pendidikan yang memadai, begitu juga laboratorium sebagai wadah eksperimen dan penelitian untuk mengembangkan ilmu pengetahuan khususnya teknik pertambangan telah tersedia. Salah satu laboratorium yang ada di Politeknik Muara Teweh adalah Laboratorium Eksplorasi dan Mekanika Batuan Program Studi Teknik Pertambangan, dimana di laboratorium ini terdapat beberapa peralatan baru sehingga perlu direncanakan instalasi penerangan yang baik agar pelaksanaan kegiatan praktikum dapat berjalan dengan baik. Berdasarkan hasil observasi yang dilakukan, Laborarorium Eksplorasi dan Mekanikan Batuan memiliki luas ruangan $60 \mathrm{~m} 2$ dan tinggi ruangan $3,2 \mathrm{~m}$ dengan indeks ruangan 1,6. Faktor refleksi dinding sebesar 0,5 dan langit-langit sebesar 0,7. Kebutuhan minimum pencahayaan untuk peralatan sesuai dengan persyaratan kerja adalah 200 lux sehingga berdasarkan hasil penelitian, diperlukan 6 armatur lampu yang masing-masing dapat menghasilkan fluks cahaya sebesar 5200 lumen dengan intensitas cahaya mencapai 413,8 candela sehingga total kuat penerangan di tengah ruangan mencapai 211 lux.
\end{abstract}

Kata Kunci : Intensitas cahaya, fluks cahaya, iluminasi, faktor refleksi, indeks ruangan.

\section{Pendahuluan}

Kebutuhan energi listrik merupakan salah satu kebutuhan yang sangat penting dalam kehidupan manusia. Hampir semua sektor dalam kehidupan masyarakat modern saat ini menggunakan energi listrik dalam menunjang segala aktivitasnya. Perkembangan teknologi yang semakin cepat, mengharuskan setiap negara berusaha meningkatkan kualitas sumber daya manusia melalui bidang pendidikan maupun penelitian. Untuk mendukung peningkatan kualitas sumber daya manusia juga diperlukan suatu lembaga pendidikan yang memiliki sarana dan prasarana yang baik seperti tersedianya laboratorium sebagai wadah untuk melaksanakan praktikum dan penelitian untuk mahasiswa.

Politeknik Muara Teweh merupakan salah satu perguruan tinggi sebagai sarana pengembangan sumber daya manusia khususnya di sekitar daerah Kabupaten Barito Utara Propinsi Kalimantan Tengah. Politeknik Muara Teweh memiliki tiga program studi dimana salah satunya adalah Program Studi Teknik Pertambangan yang diharapkan dapat mempersiapkan sumber daya manusia yang memiliki kompentensi di bidang pertambangan sehingga dapat terserap di perusahaan-perusahaan tambang yang ada di daerah Kabupaten Barito Utara dan sekitarnya. 
Politeknik Muara Teweh memiliki fasilitas gedung pendidikan yang memadai, begitu juga laboratorium sebagai wadah eksperimen dan penelitian untuk mengembangkan ilmu pengetahuan khususnya teknik pertambangan telah tersedia. Salah satu laboratorium yang ada di politeknik ini adalah Laboratorium Eksplorasi dan Mekanika Batuan, dimana di laboratorium ini terdapat beberapa peralatan baru sehingga perlu direncanakan instalasi penerangan yang baik agar pelaksanaan kegiatan praktikum dapat berjalan dengan baik. Kegiatan penelitian ini dilakukan untuk mengetahui dan merencanakan instalasi penerangan yang sesuai dengan standar penerangan khususnya untuk kebutuhan penerangan peralatan-peralatan di Laboratorium Eksplorasi dan Mekanika Batuan Program Studi Teknik Pertambangan Politeknik Muara Teweh.

\section{Metode Penelitian}

Data-data yang diperlukan dalam penelitian ini antara lain (a) data teknis dari setiap peralatan di Laboratorium Eksplorasi dan Mekanika Batuan seperti data dimensi ruang, deskripsi teknis seperti kebutuhan penerangan (lumenasi) (b). luas ruangan, denah dan konfigurasi bangunan (c). Data lainnya seperti spesifikasi teknis lampu untuk instalasi penerangan

Variabel-variabel dalam yang dipergunakan penelitian ini adalah data teknis seperti dimensi ruang seperti panjang, lebar dan tinggi setiap peralatan laboratorium. Selanjutnya luas, warna dinding dan langit-langit ruangan laboratorium dijadikan variabel penelitian untuk menentukan indeks ruangan $(k)$, faktor refleksi dinding $\left(r_{w}\right)$ dan faktor refleksi langit-langit $\left(r_{p}\right)$. Selain itu deskripsi teknis peralatan juga diperlukan untuk menentukan kebutuhan penerangan (lumenasi) dari setiap peralatan. Selain itu diperlukan beberapa tabel-tabel dari beberapa referensi tentang indeks ruang, faktor-faktor refleksi dan efisiensi armatur.

Teknik pengumpulan data dilakukan dengan mengumpulkan data-data teknis seperti dimensi ruang seperti mengukur panjang, lebar dan tinggi setiap peralatan Laboratorium Eksplorasi dan Mekanika Batuan. Setiap peralatan laboratorium akan dideskripsikanmenurut penggunaan, manfaat dan cara kerja peralatan laboratorium tersebut dapat ditentukan kebutuhan penerangan (lumenasi) dari setiap peralatan. Melakukan survei mengenai spesifikasi teknis dari lampu dan penghantar untuk menentukan lumenasi dari lampu dan jenis penghantar untuk instalasi penerangan yang ada di pasaran baik melalui referensi cetak maupun internet.

Teknik analisis data dalam penelitian ini didasarkan pada pemanfaatan Laboratorium Eksplorasi dan Mekanika Batuan merupakan ruangan yang dipergunakan sebagai tempat melaksankan praktikum yang dapat digolongkan sebagai ruang belajar sehingga berdasarkan kegunaan ruangan tersebut, kebutuhan intensitas penerangannya juga dapat ditentukan. Begitu juga dengan pendeskripsian kegunaan dan cara kerja dari peralatan-peralatan laboratorium serta pengukuran dimensi ruang dari setiap peralatan-peralatan laboratorium seperti panjang, lebar dan tinggi dari setiap peralatan dipergunakan sebagai dasar untuk menentukan intensitas penerangan yang dibutuhkan oleh setiap peralatan.

Pengamatan warna dinding dan warna langit-langit dilakukan untuk mengkonfirmasi faktor refleksi dinding 
$\left(r_{w}\right)$ dan faktor refleksi langit-langit $\left(r_{p}\right)$ sesuai dengan tabel refleksi warna. Datadata dari hasil pengukuran dimensi ruangan laboratorium seperti variabel panjang $(p)$, lebar $(l)$ dan tinggi $(t)$ ruangan dipergunakan untuk menghitung luas ruangan $(A)$ dan indeks ruangan $(k)$ dan selanjutnya indeks ruangan tersebut dipergunakan untuk menghitung efisiensi penerangan $(\eta)$ dan fluks cahaya $\left(\Phi_{\circ}\right)$ yang dibutuhkan dan jumlah armatur yang akan dipasang.

Setelah semua variabel data dikumpulkan maka dapat dihitung dan dirancang berapa intensitas cahaya yang dibutuhkan oleh setiap peralatan di Laboratorium Eksplorasi dan Mekanika Batuan Program Studi Teknik Pertambangan Politeknik Muara Teweh.

\section{Hasil dan Pembahasan}

\section{a. Data Hasil Penelitian}

Data-data yang dikumpulkan dari hasil obsevasi di Laboratorium Eksplorasi dan Mekanika Batuan berupa data-data teknis seperti data-data hasil pengamatan warna dinding dan warna langit-langit dilakukan untuk mengkonfirmasi faktor refleksi dinding $\left(r_{w}\right)$ dan faktor refleksi langitlangit $\left(r_{p}\right)$ sesuai dengan tabel refleksi warna.

Tabel 3. Hasil Pengamatan Warna Dinding dan Langit-langit Laboratorium Eksplorasi dan Mekanika Batuan

\begin{tabular}{|c|l|l|c|}
\hline No. & Media & Warna & $\begin{array}{c}\text { Faktor } \\
\text { Refleksi }\end{array}$ \\
\hline 1. & Dinding & $\begin{array}{l}\text { Kuning } \\
\text { terang }\end{array}$ & 0,5 \\
\hline 2. & $\begin{array}{l}\text { Langit- } \\
\text { langit }\end{array}$ & Putih & 0,7 \\
\hline
\end{tabular}

Selain itu data-data yang dikumpulkan dari hasil obsevasi di Laboratorium Eksplorasi dan Mekanika Batuan berupa data-data teknis seperti data-data dari hasil pengukuran dimensi ruangan laboratorium seperti variabel panjang $(p)$, lebar $(l)$ dan tinggi $(t)$ ruangan dan dimensi serta deskripsi teknis dari peralatan-peralatan seperti automatic calorimeter, core cutting machine, double roll cruiser, pulverizer, rotary sample divider dan lain-lain.

Berdasarkan observasi di lapangan, dimensi teknis peralatan-peralatan laboratorium di atas diperlukan untuk menentukan kebutuhan pencahayaan sesuai dengan Keputusan Menteri Kesehatan RI Nomor 1045/Menkes/SK/XII/2002 tentang Persyaratan Kesehatan Lingkungan Kerja Perkantoran dan Industri.

Tabel 5. Hasil Pengukuran Dimensi Peralatan, Kebutuhan Pencahayaan dan Deskripsi Kegunaan Peralatan Laboratorium Eksplorasi dan Mekanika Batuan

\begin{tabular}{|c|c|c|c|c|c|c|}
\hline \multirow[b]{2}{*}{ No. } & \multirow[b]{2}{*}{ Vima Aist } & \multicolumn{3}{|c|}{$\operatorname{Dimens}(\mathrm{m})$} & \multirow{2}{*}{ 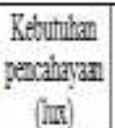 } & \multirow[b]{2}{*}{ Detsipgigi } \\
\hline & & $\begin{array}{l}\text { Paming } \\
(p)\end{array}$ & \begin{tabular}{|c|} 
Letar \\
(0)
\end{tabular} & $\begin{array}{l}\text { Timgal } \\
(t)\end{array}$ & & \\
\hline 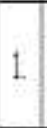 & 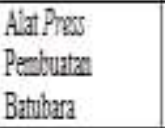 & 0,70 & 0,70 & 1,70 & 200 & Ditatiknd dil lantit \\
\hline 2. & $\begin{array}{l}\text { itlonoutic } \\
\text { Caboringter }\end{array}$ & 0,72 & 0,51 & 1,00 & 200 & 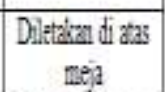 \\
\hline 3. & 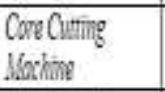 & 1,40 & 0,72 & 1,40 & 200 & Diteatiandili anti \\
\hline 4 & $\begin{array}{l}\text { Doubliboll } \\
\text { Criser }\end{array}$ & 1,00 & 0,70 & 1,00 & 200 & 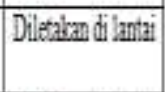 \\
\hline & Drillin & 0.45 & 0,45 & 1,15 & 200 & 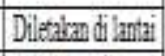 \\
\hline 6. & Oanl & 0,72 & 0,55 & 0,75 & 200 & 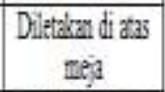 \\
\hline & OienII & 0,60 & 0,51 & 0,72 & 200 & 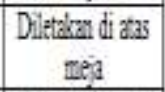 \\
\hline 8. & Pres biit & 0,35 & 0,35 & 0,85 & 200 & 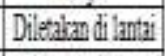 \\
\hline & Plibrices & 1,60 & 0,70 & 1,00 & 200 & 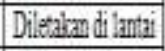 \\
\hline & $\begin{array}{l}\text { Ratary Sangle } \\
\text { Dhider }\end{array}$ & 1,10 & 0,60 & 1,20 & 200 & Dilitaknandilintil \\
\hline II. & Trboglagn Digitit & 0.65 & 0,40 & 0,088 & 200 & 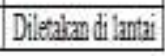 \\
\hline
\end{tabular}

\section{b. Pembahasan}

Berdasarkan data-data observasi dan hasil pengukuran dimensi ruangan dan peralatan, maka dapat dihitung kebutuhan penerangan pada pada Laboratorium Eksplorasi maupun Mekanika Batuan. 
Perhitungan kebutuhan penerangan di ruangan Laboratorium Eksplorasi dan Mekanika Batuan dapat diketahui berdasarkan data-data hasil obsevasi dan pengukuran di lapangan.

a. Data desain lampu jenis TL-HE S80 28 $\mathrm{W}$ dengan sistem penerangan sebagian langsung sedangkan konstruksi lampu terdiri dari 2 buah lampu dengan flux sebesar 2600 lumen per lampu sehingga flux cahaya $(\Phi)$ yang dihasilkan armatur sebesar $2 \times 2600=$ 5200 lumen.

b. Faktor-faktor refleksi berdasarkan warna ruangan Laboratorium Eksplorasi dan Mekanika Batuan berdasarkan Tabel 1 :

1) Faktor refleksi langitlangit $\left(r_{p}\right)$ ruangan (putih) sebesar 0,7 .

2) Faktor refleksi dinding $\left(r_{w}\right)$ ruangan (kuning muda) sebesar 0,5.

3) Faktor refleksi bidang kerja $\left(r_{m}\right)$ sebesar 0,1.

c. Data dimensi ruangan Laboratorium Eksplorasi dan Mekanika Batuan:

1) Panjang ruangan $(p)=10 \mathrm{~m}$

2) Lebar ruangan $(l)=6 \mathrm{~m}$

3) Tinggi ruangan $(t)=3,2 \mathrm{~m}$

4) Tinggi bidang kerja $(h)$ berdasarkan tinggi peralatan yang diletakan di atas lantai $=t-0,9=2,3 \mathrm{~m}$.

5) Luas ruangan $A=p \times l=10 \times 6=$ $60 \mathrm{~m}^{2}$.

Berdasarkan data dimensi ruang di atas maka dapat dihitung indeks ruangan untuk menentukan efisiensi penerangan.

Perhitungan indeks ruang berdasarkan persamaan (10) :

$$
\begin{aligned}
k=\frac{p \times l}{h(p+l)} & =\frac{10 \times 6}{2,3(10+6)} \\
& =\frac{60}{36,8}=1,6
\end{aligned}
$$

Efisiensi penerangan $(\eta)$ ruangan dapat dihitung dengan menginterpolasi nilai faktor-faktor refleksi ruangan.

Perhitungan efisiensi penerangan $(\eta)$ ruangan seperti persamaan (11) :

$$
\begin{aligned}
\eta=k_{n 1}+ & \frac{k-k_{1}}{k_{2}-k_{1}}\left(k_{n 2}-k_{n 1}\right) \\
& =0,62 \\
& +\frac{1,6-1,5}{2-1,5}(0,68 \\
& -0,62)=0,63
\end{aligned}
$$

d. Kebutuhan minimum pencahayaan $(E)$ ruang Laboratorium Eksplorasi dan Mekanika Batuan sesuai dengan Tabel 2 adalah sebesar 200 lux.

e. Faktor despresiasi (d)ditetapkan sebesar 0,8 .

f. Jumlah armatur lampu (n) yang dibutuhkan dalam ruangan dapat dihitung dengan persamaan (9) :

$$
\begin{aligned}
& n=\frac{E \times A}{\Phi \times \eta \times d}=\frac{200 \times 60}{5200 \times 0,63 \times 0,8} \\
& =4,579 \approx 5 \\
& n=5 \text { armatur. }
\end{aligned}
$$

Jumlah armatur lampu ini ditetapakan menjadi 6 armatur dengan pertimbangan teknis kebutuhan intensitas penerangan dan pembagian deret armatur menjadi 2 baris dimana masing-masing baris terdiri dari 3 armatur.

Desain pemasangan armatur di Laboratorium Eksplorasi dan Mekanika Batuan dapat dilihat pada gambar di bawah ini.

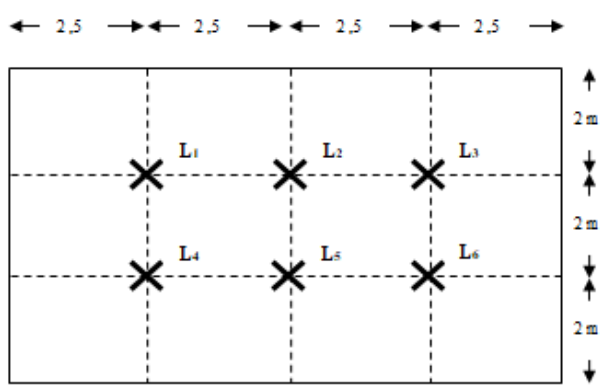

Gambar 1. Desain pemasangan armatur 
Intensitas penerangan yang diberikan oleh lampu pada baris pertama di tengah ruangan dapat dihitung dengan pemodelan seperti pada gambar 2 .

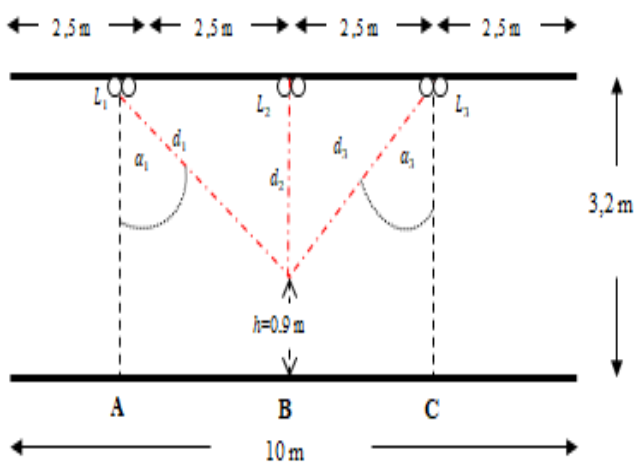

Gambar 2. Pemodelan intensitas penerangan di pusat ruangan

Jarak tegak lurus lampu pertama $\left(L_{1}\right)$ dengan pusat ruangan dapat dihitung berdasarkan Gambar 2 :

$$
\begin{gathered}
\perp L_{1}=\sqrt{2,5^{2}+1^{2}}=\sqrt{7,25} \\
=2,69 \mathrm{~m}
\end{gathered}
$$

Jarak intensitas penerangan dari lampu pertama $\left(L_{1}\right)$ ke pusat ruangan $\left(d_{1}\right)$ dapat dihitung berdasarkan pemodelan intensitas penerangan seperti pada Gambar 2.

$$
\begin{array}{r}
d_{1}=\sqrt{\left(\perp L_{1}\right)^{2}+(h)^{2}} \\
=\sqrt{(2,69)^{2}+(2,3)^{2}} \\
=\sqrt{12,52}=3,5 \mathrm{~m} \\
\cos \alpha_{1}=\frac{h}{d_{1}}=\frac{2,3}{3,5}=0,66
\end{array}
$$

Intensitas cahaya $(I)$ dari setiap lampu adalah berdasarkan Persamaan 1 adalah :

$$
I=\frac{\Phi}{\omega}=\frac{2 \times 2600}{4 \pi}
$$

Kuat cahaya di pusat ruangan $\left(E p_{1}\right)$ yang dipancarkan oleh lampu pertama $\left(L_{1}\right)$ adalah :

$$
\begin{aligned}
E p_{1}=\frac{I}{d_{1}{ }^{2}} \cdot \cos & \alpha_{1} \\
& =\frac{413,8}{(3,5)^{2}} \\
& 0,66 \\
& =22,3 \text { lux }
\end{aligned}
$$

Kuat cahaya di pusat ruangan $\left(E p_{1}\right)$ yang dipancarkan oleh lampu pertama $\left(L_{1}\right)$ ekivalen dengan kuat cahaya yang dipancarkan oleh $L_{3}, L_{4}$ dan $L_{6}$ sehingga $E p_{1}=E p_{3}=E p_{4}=E p_{6}$.

Jarak tegak lurus lampu pertama $\left(L_{2}\right)$ dengan pusat ruangan dapat dihitung berdasarkan Gambar 2 :

$$
\perp L_{5}=1 \mathrm{~m}
$$

Jarak intensitas penerangan dari lampu pertama $\left(L_{2}\right)$ ke pusat ruangan $\left(d_{2}\right)$ dapat dihitung berdasarkan pemodelan intensitas penerangan seperti pada Gambar 2 .

$$
\begin{gathered}
d_{2}=\sqrt{\left(\perp L_{2}\right)^{2}+(h)^{2}} \\
=\sqrt{(1)^{2}+(2,3)^{2}}=\sqrt{6,29} \\
=2,5 m \\
\cos \alpha_{2}=\frac{h}{d_{2}}=\frac{2,3}{2,5}=0,92
\end{gathered}
$$

Intensitas cahaya $(I)$ dari setiap lampu adalah berdasarkan Persamaan 1 adalah :

$$
I=\frac{\Phi}{\omega}=\frac{2 \times 2600}{\begin{array}{l}
4 \pi \\
=413,8 \mathrm{~cd}
\end{array}}
$$

Kuat cahaya di pusat ruangan $\left(E p_{2}\right)$ yang dipancarkan oleh lampu pertama $\left(L_{2}\right)$ adalah :

$$
\begin{aligned}
E p_{2}=\frac{I}{d_{2}{ }^{2}} \cdot \cos & \alpha_{2} \\
= & \frac{413,8}{(2,5)^{2}} \\
\cdot & 0,92 \\
& =60,9 \text { lux }
\end{aligned}
$$

Kuat cahaya di pusat ruangan $\left(E p_{2}\right)$ yang dipancarkan oleh lampu pertama $\left(L_{2}\right)$ ekivalen dengan kuat cahaya yang dipancarkan oleh $L_{5}$ sehingga $E p_{2}=E p_{5}$. 
Total kuat cahaya yang dipancarkan oleh semua lampu di pusat ruangan dapat dihitung :

$$
\begin{gathered}
\sum E_{p}=E p_{1}+E p_{2}+E p_{3}+E p_{4}+E p_{5} \\
+E p_{6} \\
=22,3+60,9+22,3+22,3 \\
+60,9+22,3 \\
=211 \text { lux. }
\end{gathered}
$$

Intensitas cahaya yang dipancarkan semua lampu dapat ditingkatkan dengan mengatur pencahayaan alami yang berasal dari jendela-jendela pada ruang Laboratorium Eksplorasi dan Mekanika Batuan. Penempatan peralatan-peralatan laboratorium yang memerlukan tingkat pencahayaan yang besar dapat diatur sedemikian rupa sehingga kebutuhan pencahayaan dapat terpenuhi sesuai dengan ketentuan dimana sumber-sumber cayahya dapat beasal dari lampu dan penerangan alami.

\section{KESIMPULAN}

Kesimpulan-kesimpulan yang dapat disampaikan dari hasil penelitian ini antara lain adalah sebagai berikut :

a. Kebutuhan intensitas penerangan untuk Laboratorium Eksplorasi dan Mekanika Batuan sebesar 200 lux sesuai dengan Keputusan Menteri Kesehatan RI Nomor 1045/Menkes/SK/XII/2002 tentang Persyaratan Kesehatan Lingkungan Kerja Perkantoran dan Industri.

b. Jumlah armatur direncanakan dalam ruang Laboratorium Eksplorasi dan Mekanika Batuan sebanyak 6 (enam) armatur dimana setiap armatur terdiri dari 2 buah lampu TL-D X-treme 830 SLV dimana fluks cahayanya sebesar 2600 lumen setiap lampu dengan konsumsi daya sebesar $28 \mathrm{~W}$ per lampu sebagai sumber pencahayaan.

c. Pemanfaatan dan pengaturan jendela juga perlu diperhatikan sebagai sumber pencahayaan alami untuk meningkatkan kuat perangan yang berasal dari lampu.

\section{V.DAFTAR PUSTAKA}

F. Suryatmo. Teknik Listrik Instalasi Penerangan, Rineka Cipta, Jakarta, 2002.

Imansyah. Perancangan Instalasi Listrik pada Rumah dengan Daya Listrik Besar, Departemen Teknik Elektro, Fakultas Teknik, Universitas Indonesia, 2009.

Keputusan Menteri Kesehatan RI Nomor 1045/Menkes/SK/XII/2002.

Persyaratan Kesehatan Lingkungan Kerja Perkantoran dan Industri, Jakarta, 2002.

Neidle, Michael. Teknologi Instalasi Listrik, Erlangga, Jakarta, 1982.

P. Van Harten, Ir. E. Setiawan. Instalasi Listrik Arus Kuat II, Binacipta, Bandung, 1985.

Phillip. Flourescent Lamp base on Ligthing Catalogue, 2008-2009.

Standar Nasional Indonesia. Persyaratan Umum Instalasi Listrik (PUIL) Tahun 2000, Jakarta, 2000. 